\title{
Study on the Cultivation of Application-Oriented Talents in Logistics Management Under the Background of Industry-Education Integration
}

\author{
Xianwen Gong ${ }^{1, \mathrm{a},{ }^{*}}$ and Jingling $\mathrm{Yu}^{1, \mathrm{~b}}$
}

\author{
${ }^{1}$ School of economics and business administration, Chongqing University of Education, Chongqing, China \\ a409895070@qq.com, ${ }^{b} 2584693900 @ q q . c o m$ \\ *Corresponding author
}

\section{ABSTRACT}

Taking logistics management as an example, this paper analyzes the problems in the training of applied talents in China. Based on the practical background of industry-education integration and school-enterprise cooperation, this paper discusses the ways to cultivate application-oriented talents for undergraduate students majoring in logistics management, and puts forward specific measures to cultivate application-oriented talents from the aspects of teaching staff, curriculum system, practice base, training orientation and practice links.

Keywords: industry-education integration, logistics management, applied talents, cultivation pathway

\section{产教融合背景下物流管理专业应用型人才培养途径研究$$
\text { 弓宪文 }{ }^{1, a, *} \text {, 于精灵 }{ }^{1, b}
$$

\footnotetext{
1 经济与工商管理学院, 重庆第二师范学院, 重庆, 中国

a409895070@qq.com, ${ }^{b} 2584693900 @ q q . c o m$

*通讯作者
}

\section{摘要}

本文以物流管理专业为例, 分析了我国应用型人才培养中面临的相关问题。基于产教融合、校企合作 的现实背景, 探讨了物流管理专业本科应用型人才培养的实现途径, 分别从师资队伍、课程体系、实 践基地、培养定位、实践环节等方面出发提出应用型人才培养的具体措施。

关键词：产教融合，物流管理，应用型人才，培养途径

\section{1. 引言}

改革开放以来, 我国社会经济结构发生了重大变革, 产业 结构得到优化调整, 行业内对技术的要求也越来越严格。 高新技术的快速发展, 使得行业内的技术手段需要不断更 新, 促使一些具有高技术要求的新岗位不断出现, 这些快 变化以及持续变化对从业人员的培养提出了新的挑战。经 济社会的高发展要求对人才的培养应当能充分体现时代 精神和符合社会发展需要, 及能够培养出具有高素质、懂 技术的应用型人才。

应用型人才培养有利于促进大学生充分利用所学的理论 知识, 提升自己的基本素质。应用型人才培养要求大学生 在校期间应该积极参加社会实践活动, 其一, 可以将其所 学理论知识转化成实际技能, 为以后的工作打下实践基 础, 提高了大学生自身的核心竞争力; 其二, 促使大学生 能够将所学的理论知识和实际问题进行分析研究, 面对自 己所缺乏的知识点和理论基础能自觉进行弥补, 充分发挥 主观能动性。这样, 大学生就可以通过应用型人才培养将 理论知识和实践知识结合起来, 进而加深对专业知识的掌 握。
应用型人才培养有利于满足企业对人才的需要, 推动企业 的快速发展。应用型人才培养不仅仅是影响个人的行为, 还会对企业的发展起到促进作用。那些具有高素质的应用 型人才, 他们可以快速进入工作状态。因此, 企业培训时 间可以大幅度减少，企业支出也相应减少，还能迅速提升 经济效益，实现企业的发展目标。

应用型人才培养有利于促进国家经济增长, 提升国家竞争 力。第三次工业革命带动了电子计算机、空间技术、信息 技术及新能源技术等一系列高科技的发展, 推动了人类社 会的进步, 但也加剧了世界各国间发展的不平衡, 贫富差 距不断扩大, 给世界经济发展带来了机遇与挑战。我国经 济的持续增长及国家竞争力的提升就离不开对高科技的 掌握和运用, 也就离不开对应用型人才的需要。应用型人 才培养注重对学生的实践能力和创新能力培养, 这都是参 与国际竞争的核心力量。

在培养目标上, 应用型人才培养的不是学科型、学术型、 研究型人才, 而是能够适应生产、建设、管理、服务第一 线需要的高等技术型人才 $[1]$ 。因此, 为满足应用型人才 目标需求应积极推动应用型本科教育, 加快构建能适应和 满足经济与社会发展的本科教学体系。我国高校自 20 世 纪 90 年代末进行扩招，短短几年时间里大学数量剧增, 
二是深化产教融合, 建立校内外导师联合教学机制。结合 物流管理专业应用型人才培养需求, 加强对学生社会实践 能力的建设, 可以与校外企业合作, 联系企业导师, 负责 对学生在相应实习中所需要的综合素质进行培养。校内导 师主要负责学生的课程学习, 培养学生的专业知识。

三是校企合作, 建立校内外教师合作学习机制。面对学院 青年教师人数较多的情况, 注重加强师资队伍的教育培 养, 可以要求一名企业老教师带领几名校内新教师, 老教 师教导新教师好的教学方法, 培养新教师的教学能力, 青 年教师带领老教师学习掌握新的教学软件, 学会在课上利 用新技术软件。这样新老教师的合作学习会提高学院教师 的整体教学水平, 增强 “双师型” 教师队伍的可建设性, 利于教师把课堂变得更加生动有趣, 提高同学们的学习热 情。

\section{3. 以企业需求为导向深化课程体系改革}

根据阳光高考网上公布的数据, 到目前为止, 全国共有 503 所本科院校开设了物流管理专业。而每年也会有好几 万物流管理专业毕业的学生。从目前来看, 虽然市场和企 业对物流管理专业人才的需求量较大, 但还是有很多毕业 生反馈说无法找到合适自己的物流工作。这其中便可能因 为传统物流专业人才培养体系不能很好地满足目前市场 经济的变化、市场和企业对人才的需求变化, 因此物流管 理专业应用型人才培养课程体系的建设是当下需要迫切 解决的重要问题。

通常情况下, 物流管理专业学习课程主要包括物流概论、 物流规划与设计、采购与供应管理、采购项目管理、运输 管理、仓储管理、配送管理、国际物流学仓储管理实务、 物流配送中心设计、国际物流实务等[7]。其培养要求是 本专业学生通过学习经济、会计、贸易、管理、法律、信 息资源管理、计算机等方面的基本理论和专门知识, 接受 物流管理方面的基本训练, 具备处理物流管理方面的能力 [8]。可以看出这些课程设置更多体现了理论性知识, 以 期培养出具备扎实的物流基础知识的学生, 来满足社会对 物流管理人才的需求。但专业理论课程门数多, 所占比例 较高, 对培养应用型人才具有一定的差距, 也不符合市场 和企业对物流管理专业人才的需求。因此, 本科物流管理 应用型人才培养方案中课程体系的建设方向应该以市场 和企业对人才的需求为主。

基于产教融合, 按照市场和企业需求进行物流管理专业课 程体系研究, 具有较强的现实意义。紧扣市场和企业的需 求, 确定大学本科四年不同阶段的培养内容, 建设特色课 程体系。一方面, 人才培养计划要根据市场和企业物流管 理不同岗位的特点而展开, 针对各岗位需求来设置专业课 程及实践主题, 还应遵循该专业的市场岗位细分后的各自 活动发展规律及学生自身的发展空间来拟定专业课程体 系; 另一方面, 物流管理专业应用型人才培养课程体系建 设必须将素质教育放于首要位置, 把学生综合素质的提高 作为最终目标。此外, 物流管理专业应用型人才培养课程 体系建设还应适应地方经济发展, 将课程体系建设融入到 地方经济建设中去, 培养出具有综合素养的应用型物流管 理人才, 通过分析行业发展的具体情况, 理清人才培养与 课程内容之间的联系, 形成可持续利用的物流管理专业应 用型人才培养课程体系[9]。 
理论, 具有国际化视野, 面向各类大中型企事业、研究设 计院所及政府管理部门, 从事运营管理、规划与设计的创 新型高端管理人才; 同济大学: 面向企业和政府相关部门, 培养能适应社会经济发展需要, 培养具备扎实的管理知识 和丰富的国际化理念, 能够掌握物流管理与工程理论和方 法，熟悉供应链管理、物流控制、信息管理、财务、金融 等工作, 能够运用信息管理与信息系统的方法, 在物流管 理领域从事全过程策划、管理和物流信息化工作的复合型 专门人才和拔尖创新人才。

与研究型人才培养定位不同, 应用型高校物流专业在进行 人才培养定位设计时, 要从产教融合出发, 考虑加快学生 与社会接轨, 让学生从社会中锻炼实践能力, 实现人才培 养与社会需求相结合, 要在人才培养方案上突出个性化与 社会化的创新点和结合点。各大高校可以在校内设立就业 服务机构, 主动定期为学生提供企业信息、就业指导、基 础工作技能培训、面试指导培训等各类中介服务, 努力营 造校园社会化的景象。高校还可以选择主动与社会各界联 系, 建立其多方位的沟通合作渠道, 推动校园与社会接轨, 让大学生毕业后不再处于 “小白” 境界, 提升大学生工作 素养, 使大学生符合满足社会对物流管理专业应用型人才 需求目标。

同时，还必须结合自身实际，精准定位。各大高校应根据 自己本身实力、层次、特点等差异进行细分, 并根据所在 地区的经济发展状况及行业发展情况进行精确定位。地方 性高校物流管理专业定位应要求精且细,避免出现大而空 的情况。在制定人才培养目标时, 注意结合学校自身的办 学优势和特点, 重点关注某些岗位群, 专注培养符合该岗 位的复合型、专业化人才。以重庆第二师范学院为例, 物 流管理专业本科学生的人才培养目标是, 培养能够迅速适 应经济社会高速发展, 具备筹划、组织、领导、控制和创 新能力的应用型高级专业化人才, 依托学校办学优势, 紧 扣 0-12 岁儿童产业链为主题, 将学校在 0-12 岁儿童教育 方面的优势资源与物流管理专业建设相联系, 面向 0-12 岁儿童产业链和重庆市地方经济发展培养应用型物流管 理人才。

\section{6. 产教融合完善人才培养的教学实践环节}

传统的人才培养模式注重发展基础教育, 缺少对实践环节 的重视。对物流管理专业应用型人才的培养虽然要求在实 践中进行, 强调实践环节, 但全国各大高校的人才培养模 式上都表现为注重发展基础教育, 理论课程较多, 实践环 节较少, 课堂教学过于封闭和传统, 很难适应现如今社会 对应用型人才的需求。在培养方案的设置中, 对实践整体 要求较低。再者, 某些高校本身专业定位不清, 存在着“光 说不练”的现象, 其教学环境很难真正完全实施实践教学, 对实践过程很难把握。就全国而言, 大多数高校的实践环 节只能在少数课程的实训和大四前的企业实习中体现, 这 对实训结果很难进行验收和及时提出建议, 也导致了实训 效果不理想, 对应用型人才培养的质量产生了严重影响。 深受传统办学思维惯性的影响, 各大高校在制定人才培养 方案时, 仅是根据科研团队研究, 遵循结合以往其他院校 的物流管理专业要求, 总结归纳创新出本校的人才培养方 案。而没有对区域经济发展趋势、行业要求变化、产业结 构变化等相关信息进行深入了解和剖析,低估了企业对物 
一广西经济管理干部学院行政管理实验室建设分析[J].中 小企业管理与科技(上旬刊),2015(07):230-231.

[2] 童宁.大众化教育时代应用型教材建设研究[J].出版广 角,2013(13):64-65.

[3] 何思远,刘澎辉.探析智慧物流背景下应用型物流人才 培养模式[J].农村经济与科技,2018,29(14):90+96.

[4] 王梦麟. 江西省转型试点院校教师专业发展研究[D]. 南昌大学,2017.

[5] 吕玉兰.应用型本科院校物流管理专业课程体系的构 建 [J].盐城工学院学报(社会科学版),2011,24(03):86-90.

[6] 许莉莉,潘小游.产教融合背景下高职院校 “双师型” 青年教师队伍建设研究 [J]. 科教导刊 (上旬 刊),2016(09):78-79.

[7] 施梅超.浅谈物流管理专业实训教学设计一一以服务 广西北部湾经济区的钦州学院为例 [J].物流工程与管 理,2011,33(06):193-195.

[8] 李杰. 秦皇岛高职院校校企合作现状与对策研究 [D]. 河北科技师范学院,2012.

[9] 耿文娟.物流管理专业应用型人才培养课程体系的建 设 [J].济南职业学院学报,2018(01):84-85+96.

[10] 刘晓静.高职院校物流管理专业实践教学探索 [J].商 场现代化,2010(15): 191.

[11] 张卓远.物流管理专业应用型人才培养课程体系的建 设[J].现代经济信息,2018(20):424.

\section{7. 结语}

经济社会的发展产生了对应用型人才的大量需求, 培养高 质量的物流管理专业应用型人才既是人力资源供给侧结 构性改革的重要内容, 也是区域经济社会和物流产业发展 的迫切需要。产教融合、校企合作不仅为物流管理专业应 用型人才的培养指明了可行方向, 也为应用型人才培养提 供了方法和途径[11]。

\section{致谢}

本研究受到重庆市科技局制度创新项目 （CSTC20119JSYJ-ZZYSBA0017）、重庆市教育科学规 划项目（2018-GX-116）、重庆市教改重点项目（182033）、 重庆市教育综合改革研究项目（19JGY42）、重庆第二师 范学院重点科研项目 (KY201707A) 的支持, 对此表示 衰心感谢。

\section{参考文献}

[1] 温顺生.应用型高职行政管理专业实验室建设探讨一 